\title{
Global standard names for the Lowermost Cambrian Series and Stage
}

1 New York State Museum, Madison Avenue, Albany, New York 12230, USA. Email: elanding@mail.nysed.gov

2 State Key Laboratory of Stratigraphy and Palaeobiology, Nanjing Institute of Geology and Palaeontology, 39 East Beijing Road, Nanjing 210008, China. Email: scpeng@nignas.ac.cn

3 School of Earth Sciences, The Ohio State University, Columbus, Ohio 43210, USA. Email: babcock.5@osu.edu

4 Institut für Paläontologie, Bayerische Julius-Maximillians-Universität, Pleicherwall 1, D97070 Würzburg, Germany.

Email: gerd.geyer@mail.uni-wuerzburg.de

5 Department of Earth Sciences, Uppsala University, Norbyvägen 22, Sweden.Email: malgo.vidal@uu.se

\begin{abstract}
The GSSP marking the base of the Cambrian System was ratified by the IUGS in 1992. Ratification of the GSSP point at the base of the Trichophycus pedum Ichnozone in the Fortune Head section, eastern Newfoundland, Canada, automatically defined the conterminant base of the lowermost series and stage of the Cambrian although names for those subdivisions were not proposed at the time of the decision. In 2007, the IUGS ratified the names Terreneuvian Series and Fortunian Stage for these previously unnamed chronostratigraphic subdivisions. The Terreneuvian Series replaces the provisional name "Series 1," and the Fortunian Stage replaces the provisional name "Stage 1," of the Cambrian System.
\end{abstract}

\section{Introduction}

The purpose of this paper is to announce the ratification of names for the lowermost stage and series of the Cambrian System. A GSSP marking the base of the Cambrian System was ratified by the IUGS in 1992 (Brasier et al., 1994; Landing, 1994). Its location is in the Fortune Head section, Burin Peninsula, eastern Newfoundland, Canada (Figures 1, 2). The Fortune Head stratotype was designated a geologic preserve in 1994.

The base of the Cambrian System is conterminant with the base of the Phanerozoic Eonothem, the Paleozoic Erathem, and the lowermost series and stage of the Cambrian. Upon ratification of the GSSP marking the base of the Cambrian in 1992 (Brasier et al., 1994; Landing, 1994), the bases of each of the conterminant boundaries were automatically ratified as well. Names had previously been established for the eon, era, and system, but names for the series and stage were left open. After much consideration, the name Terreneuvian Series was selected to replace the provisional name "Cambrian Series 1," and the name Fortunian Stage was selected to replace the provisional name "Cambrian Stage 1." Both names were ratified by IUGS in September 2007.

As currently envisioned, the Cambrian System will be divided into four series and perhaps 10 stages (Babcock et al., 2005; Peng et al., 2006; Zhu et al., 2006; Babcock and Peng, 2007). So far, the lowermost series (Terreneuvian) and uppermost series (Furongian) have received formal names (Peng et al., 2004; herein). Four stages (Fortunian, Drumian, Guzhangian, and Paibian) have received formal names (Peng et al., 2004, in review; Babcock et al., 2007; herein).

\section{Terreneuvian Series}

\section{Name of the series}

The name "Terreneuvian Series" replaces the provisional name "Cambrian Series 1." The base has been defined at a point $2.3 \mathrm{~m}$ above the base of what was referred to as "member 2" of the Chapel Island Formation (Figures 1,2) in the measured section of Narbonne et al. (1987) of the Fortune Head section, Burin Peninsula, Newfoundland, Canada. The units earlier termed members 1 and 2 of the Chapel Island Formation now comprise the lower part of the Mystery Lake Member of the Chapel Island Formation (Landing, 1996). The position of the GSSP coincides with the FAD of Trichophycus pedum and the base of the T. pedum Ichnozone as known at the time of ratification (Landing, 1994). The T. pedum Ichnozone is an assemblage-zone based on trace fossils. It reflects the appearance of complex sediment-disturbing behavior by multiple metazoans (Figure 1). The boundary is a standard age/stage GSSP. The top of the series will be defined by the base of the overlying series (provisionally called Series 2), which is presently undefined and unnamed.

The name "Terreneuvian" is derived from Terre Neuve, the modern French name for the island of Newfoundland. Terreneuvian evokes "Terre Neuffve," which, prior to a spelling reform, was the formal name for the 17th century French colony in Newfoundland. Terre Neuffve essentially corresponded to the Burin Peninsula, in the southwest of which is the GSSP. Although the Latinized variant "Terra Nova" has been used as a lithostratigraphic (Terra Nova Group) term, "Terre Neuve" has never been used previously as a lithostratigraphic or chronostratigraphic term.

\section{Correlation}

The base of the Terreneuvian Series can be correlated both biostratigraphically and geochemically: 1) at the FAD of Trichophycus pedum and the base of the T. pedum Ichnozone (Figure 1); and 2) near the onset of a large negative excursion in $\delta^{13} \mathrm{C}$ values (e.g., Armthor et al., 2003) referred to as the BACE Excursion (Basal Cambrian Carbon isotope Excursion; Zhu et al., 2006).

The base of the Terreneuvian Series is equivalent to the base of the Placentian Series as used regionally in Avalonia (Landing et al., 1989), and is roughly equivalent to the Cordubian Series as used for part of western Gondwana (i.e., Iberia and Morocco; see Geyer and Landing, 2004).

\section{Geochronology}

The Terreneuvian Epoch comprises a significant portion of the lower part of the Cambrian Period. As summarized by Shergold and Cooper (2004), the age of the base of the Cambrian System, which is 


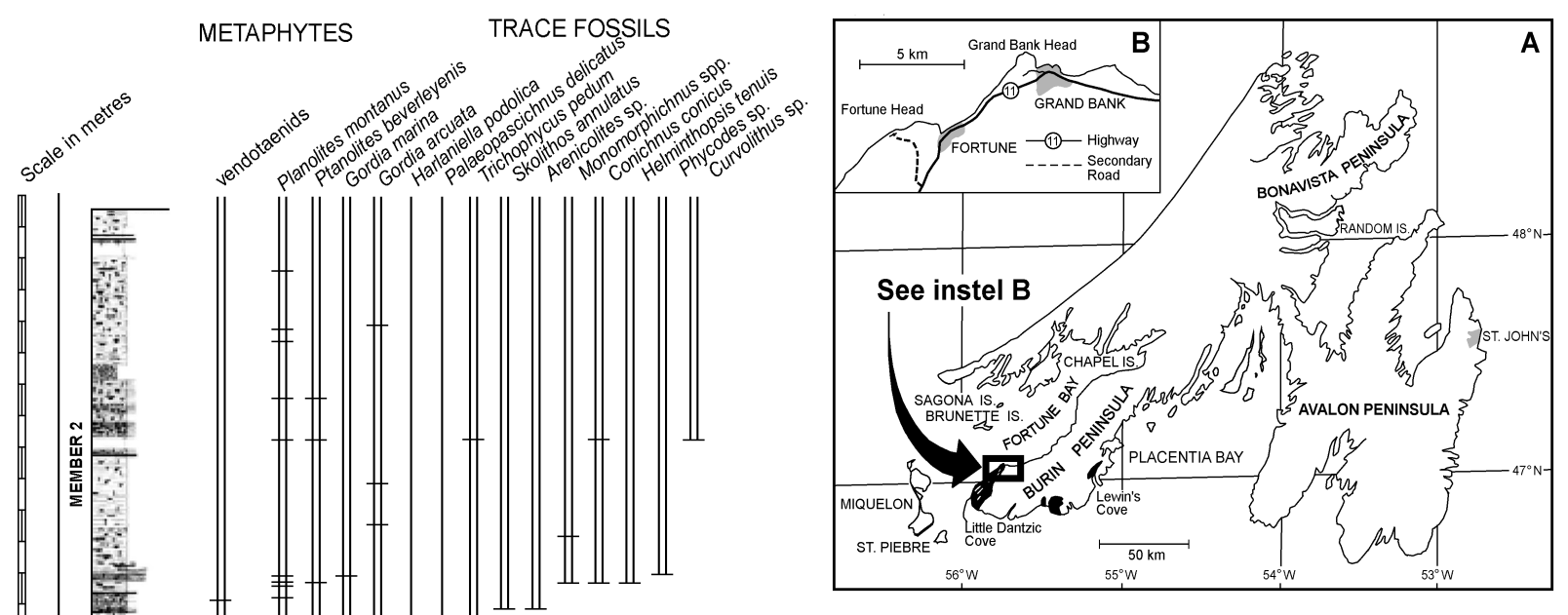

Figure 1 GSSP section for conterminant base of the Cambrian System (ratified), and its lowermost series and stage (proposed and ratified as the Terreneuvian and Fortunian respectively), and generalized locality map (upper left and lower right figures, respectively; from Narbonne et al., 1987, figs. 1,5). Note that "member 1" and "member 2" of the Chapel Island Formation now comprise the lower Mystery Lake Member (Landing, 1996). The GSSP coincides with the FAD of Trichophycus pedum. The $F A D$ of $\mathrm{T}$. pedum marks the base of the $\mathrm{T}$. pedum Ichnozone; the zone is characterized by a variety of trace fossils, most of which make their first appearances close to the base of the zone.

also the age of the base of the Terreneuvian Series and the Fortunian Stage is slightly younger than 543 Ma (Bowring et al., 1993; Brasier et al., 1994; Grotzinger et al., 1995; Tucker and McKerrow, 1995). The maximum age of the Terreneuvian base is $543 \pm 1 \mathrm{Ma}$, as determined from U-Pb zircon dates (IDTIMS) on a volcanic ash assigned to the uppermost Ediacaran System in Namibia (Grotzinger et al., 1995). Another U-Pb IDTIMS date, $539.4 \pm 1$ $\mathrm{Ma}$, was obtained from a volcanic ash in Trichophycus pedum-bearing beds that overlie an erosional unconformity in the same area of Namibia. This places an upper limit on the age of the Terreneuvian base. A U-Pb zircon date on an ash that lies approximately in the middle of the Terreneuvian Series on the Avalonian paleocontinent (i.e., southern New Brunswick) has an age of $530 \pm 1$ Ma (Isachsen et al., 1994).

The base of the Cambrian System has been approximated from drill cores in Oman (Bowring et al., 2003; Amthor et al., 2003) by the use of chemostratigraphic (the BACE excursion of Zhu et al., 2006; see also Grotzinger et al., 1995; Bartley et al., 1998; Corsetti and Hagadorn, 2001; Kimura and Watanabe, 2001; Maloof et al., 2005) and paleontologic data (extinction of the Proterozoic skeletonized fossils Namacalathus and Cloudina; see Grotzinger et al., 2000; Amthor et al., 2003). An ash bed immediately below the base of the Terreneuvian yields a U-Pb age of $543.2 \pm 0.5 \mathrm{Ma}$ (Bowring et al., 2003; Amthor et al., 2003), and an ash bed coinciding with the base of the series yields an age of $542.0 \pm 1.0 \mathrm{Ma}$ (Bowring et al., 2003; Amthor et al., 2003; see also Bowring in Shergold and Cooper, 2004).

The base of the Cambrian series provisionally called Series 2 is expected to be close to the horizon marking the first appearance of trilobites in Gondwana. That position, once it becomes ratified, will automatically define the top of the Terreneuvian Series. A U-Pb zircon date from the Avalon paleocontinent demonstrates that the earliest trilobite-bearing strata in southern Wales have a U-Pb volcanic zircon age (IDTIMS) of $519 \mathrm{Ma}$ (Landing et al., 1998).

\section{Fortunian Stage}

\section{Name of the stage}

The name "Fortunian Stage" replaces the provisional name "Cambrian Stage 1." It is the lowest stage of the Cambrian and the lower part of its first series, the Terreneuvian Series. The base of the
Fortunian Stage is conterminant with the base of the Cambrian System and the Terreneuvian Series. It is defined by a GSSP in the Fortune Head section, Burin Peninsula, Newfoundland, Canada (Brasier et al., 1994; Landing, 1994; Figures 1,2). The boundary is a standard age/stage GSSP. The top of the stage will be defined by the base of the overlying stage (provisionally called "Stage 2"), which is presently undefined and unnamed.

The name Fortunian is derived from the Grand Bank $1 \mathrm{M} / 4$ Canadian national map area in the Burin Peninsula, eastern Newfoundland, Canada. The name "Fortunian" denotes Fortune Head, Newfoundland, Canada, the site of the stratigraphic section containing the GSSP.

"Fortune" constitutes one of the few unused geographic names available for use as a chronostratigraphic term in the Fortune Head area. A "Fortune Formation" had been proposed (Heyl, 1936) in north-central Newfoundland for Ordovician trench-fill deposits, but has been abandoned (see Lexicon of Canadian Geologic Units,

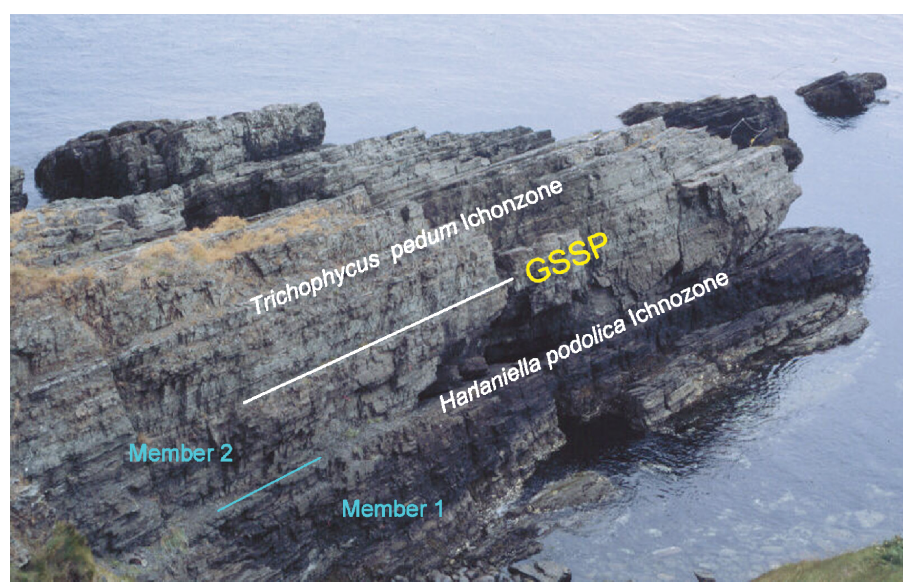

Figure 2 Coastal outcrop at Fortune Head, Burin Peninsula, Newfoundland, Canada, showing the GSSP section and point for the base of the Cambrian System. The GSSP is conterminant with the base of the Phanerozoic Eonothem, Paleozoic Eonothem, Terreneuvian Series, and Fortunian Stage. Use of "member 1" and "member 2" follows Narbonne et al. (1987). Together, these units now comprise the lower Mystery Lake Member of the Chapel Island Formation (Landing, 1996). 
2007) as unrecognizable and ambiguous for mapping purposes (Helwig, 1969; Horne and Helwig, 1969).

Correlations and geochronology of the base of the Fortunian Stage were discussed in the preceding section on the Terreneuvian Series.

The base of provisional Stage 2, which will mark the top of the Fortunian Stage, is undefined. However, the position is likely to be close to the middle of the Terreneuvian Series. Middle Terreneuvian strata in New Brunswick, Canada, as noted above, have yielded a U$\mathrm{Pb}$ zircon age of $530 \mathrm{Ma}$ (Isachsen et al., 1994). Numerous ashes occur in the lower Fortunian Stage (Landing, 2004; E. Landing and S.A. Bowring, unpublished data), and will likely provide dates on the lowest occurrence of diverse small shelly fossils and the pace of the Cambrian radiation.

\section{Acknowledgments}

We would like to thank the members of the International Subcommission on Cambrian Stratigraphy for helpful discussion on the choice of names for the lowermost Cambrian series and stage. This work was supported in part by grants to Landing from the U.S. National Science Foundation (EAR 83-12939, EAR 93-38774, EAR 98-5177, 0116551); to Peng from the National Natural Science Foundation of China (40072003, 40023002, 40332018), the Major Basic Research Project of Ministry of Technology and Science of China (2006CB806408, 2006FY120300), the Chinese Academy of Science (KZCX2-YW-122), and the Geological Surveying Project of China Geological Survey and National Stratigraphical Commission of China (200113000076); and to Babcock from the U.S. National Science Foundation (EAR 0106883, EAR OPP-0346829).

\section{References}

Amthor, J.E., Grotzinger, J.P., Schröfer, S., Bowring, S.A., Ramezani, J., Martin, M.W., and Matter, A., 2003, Extinction of Cloudina and Namacalathus at the Precambrian-Cambrian boundary. Geology, v. 31, pp. 431-434.

Babcock, L.E., and Peng, S., 2007, Cambrian chronostratigraphy: current state and future plans. Palaeogeography, Palaeoclimatology, Palaeoecology, doi:10.1016/j.palaeo.2007.03.011.

Babcock, L.E., Peng, S.C., Geyer, G., and Shergold, J.H., 2005. Changing perspectives on Cambrian chronostratigraphy and progress toward subdivision of the Cambrian System. Geosciences Journal, v. 9, pp. 101-106.

Babcock, L.E., Robison, R.A., Rees, M.N., Peng, S.C., and Saltzman, M.R., 2007. The Global boundary Stratotype Section and Point (GSSP) of the Drumian Stage (Cambrian) in the Drum Mountains, Utah, USA. Episodes, v. 30, pp. 84 94.

Bartley, J.K., Pope, M., Knoll, A.H., Semikhatov, M.A., and Petrov, P.Y., 1998, A Vendian-Cambrian boundary succession from the northwestern margin of the Siberian Platform: stratigraphy, paleontology, chemostratigraphy and correlation. Geological Magazine, v. 135, pp. 473-494.

Bowring, S.A., Grotzinger, J.P., and Isachsen, C.E., 1993, Calibrating rates of Early Cambrian evolution. Science, v. 261, pp. 1293-1298.

Bowring, S.A., Ramezani, J., and Grotzinger, J.P., 2003, High-precision U-Pb geochronology and the Cambrian-Precambrian boundary, in NUNA Conference 2003, New Frontiers in the Fourth Dimension: Generation, Calibration and Application of Geological Timescales, Mont Tremblant, Quebec. Geological Association of Canada.

Brasier, M.D., Cowie, J., and Taylor, M., 1994, Decision on the Precambrian-Cambrian boundary. Episodes, v. 17, pp. 95-100.

Corsetti, F.A., Hagadorn, J.W., 2001. The Precambrian-Cambrian transition in the southern Great Basin, USA. The Sedimentary Record, v.1, no. 1, pp. 4-8.

Geyer, G., and Landing, E., 2004, A unified Lower-Middle Cambrian chronostratigraphy for West Gondwana. Acta Geologica Polonica, v. 54, pp. 179-218.

Grotinger, J.P., Bowring, S.A., Saylor, B.Z., and Kaufman, A.J., 1995, Biostratigraphic and geochronologic constraints on early animal evolution. Science, v. 270, pp. 598-604.

Grotzinger, J.P., Watters, W.A., and Knoll, A.H., 2000, Calcified metazoans in thrombolite-stromatolite reefs of the terminal Proterozoic Nama Group, Namibia. Paleobiology, v. 26, pp. 334-359.

Helwig, J., 1969, Redefinition of Exploits Group, Lower Paleozoic, northeast Newfoundland, in Kay, M. (ed.), North Atlantic-Geology and continental drift. American Association of Petroleum Geologists Bulletin, v. 12, pp. 408-413.
Heyl, G.R., 1936, Geology and mineral deposits of the Bay of Exploits area. Newfoundland Department of Natural Resources, Geological Section Bulletin 3, 66 pp.

Horne, G.S., and Helwig, J., 1969, Ordovician stratigraphy of Notre Dame Bay, Newfoundland., in Kay, M. (ed.), North Atlantic-Geology and continental drift. American Association of Petroleum Geologists Bulletin, v. 12, pp. 388-407.

Isachsen, C.E., Bowring, S.A., Landing, E., and Samson, S.D., 1994, New constraint on the division of Cambrian time. Geology, v. 22, pp. 496-498.

Kimura, H., and Watanabe, Y., 2001, Oceanic anoxia at the Precambrian-Cambrian boundary. Geology, v. 29, pp. 995-998.

Landing, E., 1994, Precambrian-Cambrian boundary global stratotype ratified and a new perspective of Cambrian time. Geology, v. 22, pp. 179-182.

Landing, E., 1996, Avalon-insular continent by the latest Precambrian, in R.D. Nance, R.D., and Thompson, M. (eds.), Avalonian and related peri-Gondwanan terranes of the circum-North Atlantic. Geological Society of America Special Paper 304, pp. 27-64.

Landing, E., 2004, Precambrian-Cambrian boundary interval deposition and the marginal platform of the Avalon microcontinent. Journal of Geodynamics, v. 37, pp. 411-435.

Landing, E., Myrow, P., Benus, A.P., and Narbonne, G.M., 1989, The Placentian Series: appearance of the oldest skeletalized faunas in southeastern Newfoundland. Journal of Paleontology, v. 63, pp. 739-769.

Landing, E., Bowring, S.A., Davidek, K., Westrop, S.R., Geyer, G., and Heldmaier, W., 1998, Duration of the Early Cambrian: U-Pb ages of volcanic ashes from Avalon and Gondwana. Canadian Journal of Earth Sciences, v. 35, pp. 329-338.

Lexicon of Canadian Geologic Units, 2007, http://cgkn1.cgkn.net/ weblex/weblex_list_e.pl, 13 June 2007.

Maloof, A.C., Schrag, D.P., Crowley, J.L., and Bowring, S.A., 2005, An expanded record of Early Cambrian carbon cycling from the Anti-Atlas margin, Morocco. Canadian Journal of Earth Sciences, v. 42, pp. 2195-2216.

Narbonne, G.M., Myrow, P., Landing, E., and Anderson, M.M., 1987, A candidate stratotype for the Precambrian-Cambrian boundary, Fortune Head, Burin Peninsula, southeastern Newfoundland. Canadian Journal of Earth Sciences, v. 24, 1277-1293.

Peng, S.C., Babcock, L.E., Robison, R.A., Lin, H.L., Rees, M.N., and Saltzman, M.R., 2004, Global Standard Stratotype-section and Point (GSSP) of the Furongian Series and Paibian Stage (Cambrian). Lethaia, v. 37, pp. 365-379.

Peng, S.C., Babcock, L.E., Geyer, G., and Moczydlowska, M., 2006, Nomenclature of Cambrian epochs and series based on GSSPs-comments on an alternative proposal by Rowland and Hicks. Episodes, v. 29, pp. 130-132.

Peng, S.C., Babcock, L.E., Zuo , J.X., Lin , H.L., Zhu, X.J., Yang, X.F., Robison, R.A., Qi, Y.P., Bagnoli, G., and Chen, Y., in review, The Global boundary Stratotype Section and Point of the Guzhangian Stage (Cambrian) in the Wuling Mountains, northwestern Hunan, China. Episodes.

Shergold, J.H., and Cooper, R.A., 2004, The Cambrian Period, in Gradstein, F.M., Ogg, J.G., and Smith, A.G. (eds.), A Geologic Time Scale 2004. Cambridge University Press, Cambridge, pp. 147-164.

Zhu, M.-Y., Babcock, L.E., and Peng, S.C., 2006, Advances in Cambrian stratigraphy and paleontology: integrating correlation techniques, paleobiology, taphonomy and paleoenvironmental reconstruction. Palaeoworld, v. 15, pp. 217-222.

Ed Landing is the New York State Paleontologist and Curator of Paleontology at the New York State Museum, Albany, New York, USA. His Cambrian research focuses on the Laurentian, west Gondwanan, and Avalonian paleocontinents; evolution and habitats of early skeletalized metazoans; and eustasy and its relationship to climate and oceanic oxygenation. His current research includes the sequence stratigraphy and conodont and macrofossil biostratigraphy of eastern Laurentia. He is a voting member of the International Subcommission on Cambrian Stratigraphy.

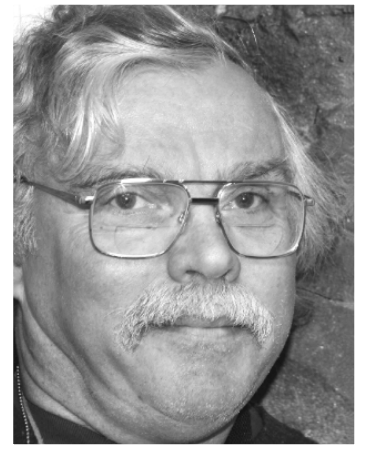

